\title{
ITGB1 wt Allele
}

National Cancer Institute

\section{Source}

National Cancer Institute. IT GB1 wt Allele. NCI Thesaurus. Code C96909.

Human IT GB1 wild-type allele is located in the vicinity of 10p11.2 and is approximately 58 $\mathrm{kb}$ in length. This allele, which encodes integrin beta-1 protein, is involved in ligand binding, signal transduction, cell-matrix adhesion and leukocyte migration. 